
December 1944

\title{
PREPARING REFRACTORY OXIDES, SILICATES, AND CERAMIC MATERIALS FOR ANALYSIS, BY HEATING WITH ACIDS IN SEALED TUBES AT ELEVATED TEM- PERATURES
}

By

\author{
Edward Wichers, William G. Schlecht, and Charles L. Gordon
}

ABSTRACT

This paper describes the preparation for analysis of a number of refractory oxides, ceramic materials, and minerals by decomposition with hydrochloric or hydriodic acid at temperatures up to $300^{\circ} \mathrm{C}$. All the oxides of the elements in the second, third, and fourth groups of the periodic system, with the exception of silica, titania, zirconia, and possibly hafnia, respond to the treatment. A number of silicate minerals, ordinarily difficult to prepare for analysis, are likewise successfully decomposed.

\section{CONTENTS}

I. Introduction ___

II. Treatment with hydrochloric acid

1. Aluminum oxide, clav, and siliceous materials high in alumina .452

2. Other refractory oxides ................. 452

3. Minerals _._.

4. Rocks_...

III. Treatment with hydriodic acid

IV. Contamination of the sample by dissolved oxides from the sealed tube _. 455

\section{INTRODUCTION}

The work already reported on the preparation of refractory platiniferous materials for analysis ${ }^{1}$ led naturally to trials of a similar procedure for attacking various minerals and ceramic materials that are difficult to decompose by the analyst's customary methods. Jannasch ${ }^{2}$ used such a method some 50 years ago. He treated refractory silicate rocks with hydrochloric acid in sealed tubes at temperatures up to $400^{\circ} \mathrm{C}$. To prevent contaminating the solutions with silica and other constituents of the glass, he placed the samples in loosely stoppered platinum capsules inside the sealed glass tubes, with acid both inside and outside the capsules. If air was not displaced from the tube before it was sealed, considerable platinum dissolved. Jannasch's method apparently has not come into general use, but the procedure seems worthy of further consideration, especially

\footnotetext{
${ }_{1}^{1}$ E. Wichers, W. G. Schlecht, and C. L. Gordon, Attack of refractory platiniferous materials by acid mixtures at elevated temperatures, J. Research NBS 33, 363 (1944) RP1614.

2 P. Jannasch, Ber. deut. chem. Ges. 24, 273 (1891); Z. anorg. Chem. 6, 72 (1894).
} 
since modern laboratory glass is so little attacked by hydrochloric acid at high temperatures.

The equipment used in the trials here reported was the same as that described for dissolving iridium and its alloys, and is described in detail in a third paper. ${ }^{3}$ In many instances samples weighing $0.1 \mathrm{~g}$ were used. These were treated with $1 \mathrm{ml}$ of hydrochloric acid (36 weight-percent $\mathrm{HCl}$ ) in $4-$ by $8-\mathrm{mm}$ tubes, about $20 \mathrm{~cm}$ long. These tubes required no external protection. Larger samples were treated in tubes of suitable size (up to $15-\mathrm{mm}$ bore). In these larger tubes the internal pressure developed during treatment of the sample was compensated for by external pressure of carbon dioxide within a steel container.

\section{TREATMENT WITH HYDROCHLORIC ACID}

\section{ALUMINUM OXIDE, CLAY, AND SILICEOUS MATERIALS HIGH IN ALUMINA}

One of the first materials to be tried was sintered aluminum oxide, which had to be examined for a minute content of sulfate (about 0.01 percent). Ignited alumina is, of course, wholly unattacked by hydrochloric acid at temperatures attainable in open vessels. Even at $160^{\circ} \mathrm{C}$ there was no visible attack in 4 hours, but at $260^{\circ} \mathrm{C}$ the material was brought completely into solution within 15 hours with a quantity of hydrochloric acid only 10 percent in excess of the stoichiometric requirement. The resulting solution was a nearly ideal one in which to determine sulfate by means of precipitation with barium chloride. The alternative procedure of fusing the samples with sodium carbonate or with borax not only might have introduced sulfur compounds in amounts as large as those in the sample, but would have yielded a solution containing an undesirable amount of alkali salts.

Later a 2-g sample of fused aluminum oxide in the form of a 60-mesh powder was completely dissolved in $20 \mathrm{ml}$ of hydrochloric acid in 35 hours at $300^{\circ}$ C. Burnt alumina refractories (NBS Standard Samples 76 and 78) were completely decomposed by treatment at $300^{\circ} \mathrm{C}$ for 24 hours. In these and most of the other trials no attempt was made to determine the optimum conditions of treatment but only to find out whether the method appeared to be useful for a considerable variety of materials. In the course of these trials there was occasion to prepare for analyses a considerable number of porcelains containing 36 to 97 percent of alumina and up to 57 percent of silica. All of these were successfully decomposed at $300^{\circ} \mathrm{C}$.

\section{OTHER REFRACTORY OXIDES}

Beryllium oxide that had been ignited at $1,500^{\circ} \mathrm{C}$ was completely dissolved within 16 hours at $250^{\circ} \mathrm{C}$. Bolivian tin ore, largely cassiterite, was incompletely attacked at $200^{\circ} \mathrm{C}$ but completely decomposed in 24 hours at $250^{\circ} \mathrm{C}$. Ceric oxide was completely at-

${ }^{3}$ C. L. Gordon, W. G. Schlecht, and E. Wichers, Use of sealed tubes for the preparation of acid solutions of samples for analysis, or for small scale refining: Pressures of acids heated above $100^{\circ} \mathrm{C}$, J. Research NBS 33 ,
457 (1944) RP1622. 
tacked at $300^{\circ} \mathrm{C}$ in 18 hours, and equally well when nitric acid was used instead of hydrochloric acid. Nitric acid was found to attack fused alumina only slightly in 72 hours at $300^{\circ} \mathrm{C}$. Titanium and zirconium oxides showed no sign of attack by concentrated hydrochloric acid in 18 hours at $300^{\circ} \mathrm{C}$. Raising the temperature to $350^{\circ} \mathrm{C}$ resulted in a slight attack of the zirconia in a 4-hour period. A slight attack was also accomplished at $250^{\circ} \mathrm{C}$ with specially fortified hydrochloric acid (75 weight-percent of $\mathrm{HCl})$ in a 16-hour period. Neither variation resulted in significant attack of titanium oxide. In view of the resistance of zirconium oxide to hydrochloric acid, it was of special interest to find that a ceramic material containing about 50 percent of zirconia and 35 percent of silica could be successfully decomposed for analysis. This was also done with a special ceramic material containing 10 percent of zirconia, 80 percent of thorium oxide, and 10 percent of yttrium oxide.

\section{MINERALS}

In studying the attack of various minerals, weighed samples of approximately $0.1 \mathrm{~g}$ were treated with $1 \mathrm{ml}$ of acid for 48 hours at $300^{\circ} \mathrm{C}$. When the tubes were opened the undissolved residue was collected on filter paper, washed, and ignited. It was then treated with hydrofluoric and sulfuric acids to volatilize the silica. The difference between the weight of sample taken and the weight of the residue after this treatment was taken as a measure of the degree of completeness of the attack. The following minerals were found to be completely attacked, or substantially so in the sense that the weight of residue was less than 1 percent of the weight of the sample taken: Muscovite, amphibole, $\mathrm{Ab}_{3} \mathrm{An}_{97}$ (anorthite), tourmaline, clinochlore, cordierite (iolite), sillimanite, spinel, and chromite. A number of others left residues not exceeding about 5 percent of the sample weight and were classified as nearly completely attacked. They were $\mathrm{Ab}_{52}$ $\mathrm{An}_{48}$ (andesine), talc, diaspore, allanite, $\mathrm{Ab}_{20} \mathrm{An}_{80}$ (bytownite), allmandite garnet, and sphene (titanite). It seems not unlikely that some variation in the treatment of these specimens would have resulted in complete attack. Beryl, topaz, orthoclase, samarskite, and dumortierite were partially decomposed by the treatment described, whereas $\mathrm{Ab}_{63} \mathrm{An}_{37}$ (andesine), $\mathrm{Ab}_{96} \mathrm{An}_{4}$ (albite), and $\mathrm{Ab}_{80} \mathrm{An}_{20}$ (oligoclase) were virtually unattacked.

The albite-anorthite series of minerals was of special interest because the degree of attack ranged from none for albite to complete for anorthite. These minerals responded as shown in table 1 . The refractive indices of most of these minerals were determined by C. P. Saylor of this Bureau. The compositions of these minerals were then obtained from the relation between the refractive index and the albite to anorthite ratio. ${ }^{4}$ The relation between the attack by hydrochloric acid and the silica content of the mineral plotted as a function of the composition is shown in figure 1.

E. S. Larsen and H. Berman, The Microscopic Determination of the Nonopaque Minerals [2d ed.] Bul. 848, U. S. Geological Survey. 

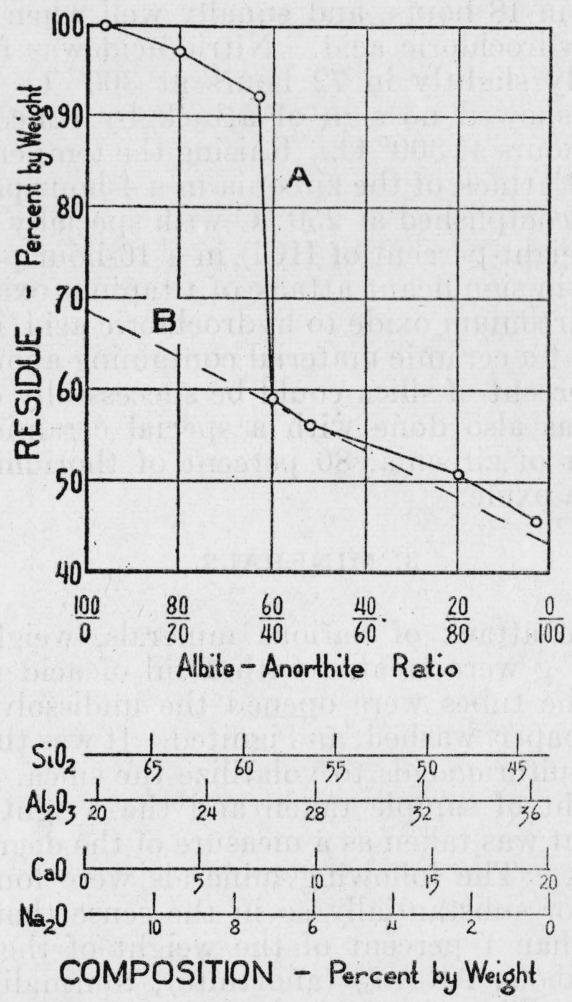

Figure 1.-Decomposition of the albite-anorthite series of plagioclase feldspars by hydrochloric acid at $300^{\circ} \mathrm{C}$.

$A$, percentage by weight of minoral undissolved after 48 hours; $B$, percentage by weight of slica in the mineral (theoretical).

TABLE 1.-Degree of attack of the albite-anorthite series of plagioclase feldspars

\begin{tabular}{|c|c|c|c|c|c|c|}
\hline \multirow{2}{*}{ Mineral 4} & \multicolumn{4}{|c|}{ Composition by weight 1} & \multirow{2}{*}{$\begin{array}{l}\text { Percentage } \\
\text { of sample } \\
\text { undis- } \\
\text { solved }^{2}\end{array}$} & \multirow{2}{*}{$\begin{array}{l}\text { Percentage } \\
\text { of sample } \\
\text { lost by } \\
\text { HF treat- } \\
\text { ment }{ }^{3}\end{array}$} \\
\hline & $\mathrm{SiO}_{2}$ & $\mathrm{Al}_{2} \mathrm{O}_{3}$ & $\mathrm{CaO}$ & $\mathrm{Na}_{2} \mathrm{O}$ & & \\
\hline 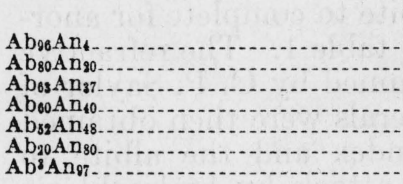 & $\begin{array}{r}\% \\
68 \\
64 \\
59 \\
58 \\
56 \\
48 \\
44\end{array}$ & $\begin{array}{r}\% \\
20 \\
23 \\
26 \\
26 \\
28 \\
33 \\
36\end{array}$ & $\begin{array}{r}\% \quad 1 \\
4 \\
7 \\
7 \\
8 \\
10 \\
16 \\
20\end{array}$ & $\begin{array}{r}\% \\
11 \\
9 \\
7 \\
7 \\
6 \\
2 \\
0\end{array}$ & $\begin{array}{r}100.0 \\
97.1 \\
92.3 \\
59.0 \\
56.1 \\
50.8 \\
45.7\end{array}$ & $\begin{array}{l}39.8 \\
32.9 \\
50.2 \\
56.6 \\
50.1 \\
49.1 \\
44.5\end{array}$ \\
\hline
\end{tabular}

1 From index measurements by C. P. Saylor.

2 Undissolved residue after filtration of the contents of the sealed tube and ignition of the paper.

${ }^{3}$ Determined by treatment of the residue with hydrofluoric acid and sulfuric acid, followed by ignition to oxides.

$\mathrm{A} \mathrm{b}=$ albite; $\mathrm{An}=$ anorthite. 


\section{ROCKS}

Two rocks, reddish andesite and rhyolite, were also tried. They were partially attacked and no difference was found in the degree of attack in periods of 2 and 3 days at $300^{\circ} \mathrm{C}$. Apparently, certain constituents of these rocks were rather readily decomposed, whereas others remained unattacked. The difference in this respect between such minerals as mica and the feldspars suggests that the treatment might be useful in determining the amounts of these minerals in granites.

Bauxite (NBS Standard Sample 69) was completely attacked.

\section{TREATMENT WITH HYDRIODIC ACID}

Caley and Burford ${ }^{5}$ used hydriodic acid for the solution of some difficultly soluble compounds. They noted that the alkaline earth sulfates are not decomposed by cold hydriodic acid but decompose at higher temperatures. Trials with the sealed 2-ml tubes containing $1 \mathrm{ml}$ of hydriodic acid (56 weight-percent of $\mathrm{HI}$ ) and $0.100 \mathrm{~g}$ of material were made at $300^{\circ} \mathrm{C}$ for 48 hours. Barium sulfate was found to be completely decomposed, as was fused alumina (60 mesh). Sillimanite and anorthite were nearly completely attacked, but andesine, orthoclase, oligoclase, and zirconia were unattacked, as compared with slight attack by hydrochloric acid. It was found in the case of the minerals that the attack by hydriodic acid (56 weight-percent of $\mathrm{HI}$ ) was in general slightly less than by hydrochloric acid (36 weightpercent of $\mathrm{HCl}$ ) at the same temperature.

\section{CONTAMINATION OF THE SAMPLE BY DISSOLVED OXIDES FROM THE SEALED TUBE}

The attack of Pyrex glass under the conditions described is small enough to cause no concern in making many types of analyses. The principal constituents of Pyrex laboratory glass are the oxides of silicon, boron, aluminum and sodium. In careful analytical work the removal of these constituents from the glass must be taken into account. The magnitude of the attack is illustrated by a "blank" experiment in which $5 \mathrm{ml}$ of hydrochloric acid (36 weight-percent of $\mathrm{HCl}$ ) was heated at $300^{\circ} \mathrm{C}$ for 24 hours. The resulting solution was rinsed into a platinum crucible, evaporated, and the residue dried at $100^{\circ} \mathrm{C}$. After treatment with sulfuric acid and ignition, it weighed $0.0032 \mathrm{~g}$, of which $0.0018 \mathrm{~g}$ was lost by treatment with hydrofluoric and sulfuric acids in the usual manner. The tube had an internal surface area of $12 \mathrm{~cm}^{2}$, hence the amount of material removed from the glass, as weighed after treatment with sulfuric acid and ignition, was $0.00026 \mathrm{~g} / \mathrm{cm}^{2}$.

For work in which the degree of attack on the glass is excessive, recourse can be had to Jannasch's device of capsules of platinum within the sealed glass tubes. This involves the disadvantage of keep-

8 E. R. Caley and M. G. Burford, Ind. Eng. Chem., Anal. Ed. 8, 63-7 (1936). 


\section{Journal of Research of the National Bureau of Standards}

ing the tubes upright, with a consequent slower rate of attack than when the sample can be distributed along the length of the tube. An alternative method is to use a platinum-lined pressure vessel of steel. To avoid the attack of platinum that Jannasch observed, the air in the tube can be displaced with some inert gas or, more simply, a small amount of sulfur dioxide can be added to the hydrochloric acid. A number of trials showed that the optimum concentration of sulfur dioxide for this purpose is $0.0013 \mathrm{~g} / \mathrm{ml}$ of acid. Smaller amounts failed to protect the platinum completely, and larger amounts resulted in the deposition of sulfur.

Washington, May 25, 1944. 